Summary. In meristematic root tip cells of Scilla sibirica $(2 n=12$ and $3 n=18)$ the following results were obtained with the aid of autoradiography: 1 . The average duration of the mitotic cycle $(2 n=12)$ is $69.5 \mathrm{~h}$. The $\mathrm{G}_{1^{-}}$ phase lasts $36.5 \mathrm{~h}$, the DNA synthetic phase $17.5 \mathrm{~h}$, the
$\mathrm{G}_{2}$-phase $8 \mathrm{~h}$ and mitosis $7.5 \mathrm{~h} .2$. There are no marked differences in the lengths of the cell cycles nor in the duration of the various phases between diploid and triploid plants.

T. W. BaUmann 20
20 Jetzige Adresse: University of Southern California, Allan Hancock Foundation, University Park, Los Angeles (California 90007, USA).
Institut für Allgemeine Botanik der Universität Zürich, Künstlergasse 76, CH-8006 Z ürich (Schweiz), 16 November 1971.

\title{
Antarctic Seal Serum Proteins, Glycoproteins and Lipoproteins
}

In order to complete our investigations on Antarctic animals ${ }^{1-3}$, we have studied the serum proteins, lipoproteins, glycoproteins and total lipids of the Antarctic seal (Leptonychotes wedelii).

This report was carried out on the sera of seals captured in the Argentinian Antarctic Base Almirante Brown (Lat. $64^{\circ} 52^{\prime}$ S., Long. $62^{\circ} 53^{\prime}$ W.).

The sera of 20 animals were analyzed and the results shown in Tables I-III expresses their average.

The estimation of total proteins was made with the Folin-Ciocalteu phenol reagent. Fractioned serum proteins, glycoproteins and lipoproteins were determined by cellulose acetate electrophoresis ${ }^{4-10}$ (Figure). Total lipids were determined by a method based on the sulfo-phosphovainillin reaction ${ }^{\mathrm{II}}$.

The results shown in Tables I and II do not differ greatly from the normal values of the other mammalian

Table I. Proteins

\begin{tabular}{|c|c|c|}
\hline & $\bar{x}$ & $\begin{array}{l}2 \mathrm{SD} \\
(\mathrm{g} / 100 \mathrm{ml})\end{array}$ \\
\hline Total proteins & \multicolumn{2}{|c|}{$7.07 \pm 0.85$} \\
\hline Albumin & \multicolumn{2}{|c|}{$5.12 \pm 0.68$} \\
\hline$\alpha_{1}$ globulins & \multicolumn{2}{|c|}{$0.20 \pm 0.05$} \\
\hline$\alpha_{2}$ globulins & \multicolumn{2}{|c|}{$0.55 \pm 0.14$} \\
\hline$\beta$ globulins & \multicolumn{2}{|c|}{$0.98 \pm 0.25$} \\
\hline$\gamma$ globulins & \multicolumn{2}{|c|}{$0.85 \pm 0.20$} \\
\hline
\end{tabular}

The results express the average of 20 animals.

Table II. Glycoproteins

\begin{tabular}{lr}
\hline & $\bar{x}$ \\
\hline Total glycoproteins & $12.1 \% \pm 3.0$ of the total proteins \\
$\alpha$ glycoproteins & $75.4 \% \pm 9.5$ of the glycoproteins \\
$\beta$ glycoproteins & $8.3 \% \pm 1.9$ of the glycoproteins \\
$\gamma$ glycoproteins & $17.5 \% \pm 3.3$ of the glycoproteins \\
\hline
\end{tabular}

The results express the average of 20 animals.

Table III. Total lipids and lipoproteins

\begin{tabular}{lcc}
\hline & $\bar{x}$ & $2 \mathrm{SD}$ \\
\hline Total lipids & $8.25 \pm 0.11 \mathrm{mg} / 100 \mathrm{ml}$ \\
$\alpha$ lipoproteins & $14.9 \% \pm 4.3$ of the total lipoproteins \\
$\beta$ lipoglobulins & $85.1 \pm 6.9$ of the total lipoproteins \\
$\beta / \alpha$ ratio & $5.6 \pm 0.5$ \\
\hline
\end{tabular}

The results express the average of 20 animals. species, although lipids and lipoproteins (Table III) are increased.

This fact can be explained because these animals utilize lipids and lipoproteins as reserve material ${ }^{12}$.

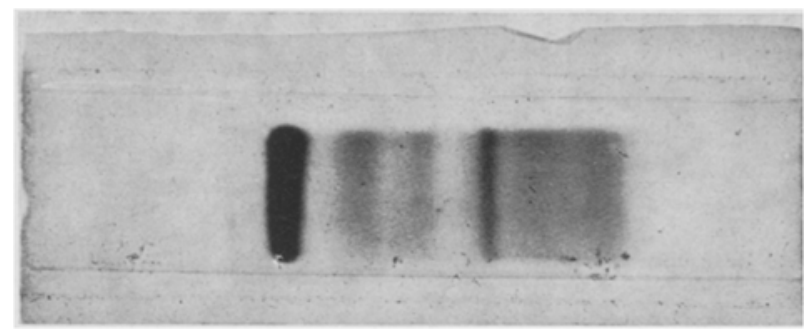

Gel acetate electrophoresis of seal serum.

Résumé. On a étudié les variations qualitatives et quantitatives des protéines sériques, lipoprotéines et glycoprotéines des phoques antarctiques, et on a trouvé que seulement les lipoprotéines et les lipides totales sont augmentées par rapport à celles des autres mammifères.

R. A. Margni, Silvia E. Hajos and Margarita Romero Mercado

University of Buenos Aires,

Faculty of Pharmacy and Biochemistry,

Buenos Aires (Argentina), 6 December 1977.

${ }^{1}$ R. A. Margni and O. D. Castrelos, Contribución No 75. Instituto Antártico Argentino (Buenos Aires) (1963).

2 R. A. MARGNI and O. D. CASTRELOS, Quelques aspects de la bacteriologie antartique (Eds. R. Corrick, M. Holdgate and S. Prevost; Ed. Herman, Paris 1964), p. 121.

${ }^{3}$ R. A. MARGNi, O. D. Castrelos and M. R. Herrera, Contribución No 102. Instituto Antártico Argentino (Buenos Aires) (1967).

4 O. H. Lowry, N. J. Rosebrough, L. Farr and R. J. Randall, J. biol. Chem. 193, 265 (1951).

5 E. O. Acerbo, R. A. Margni and E. E. Heer, Archos Fund RouxOcefa. 3, 91 (1969)

${ }^{6}$ R. A. Margnt, E. O. Acerbo, E. E. Heer and S. E. Hajos, Clin. chim. Acta 28, 451 (1970).

7 R. A. Margni, E. E. Heer, E. O. Acerbo, S. E. Hajos, M. BeliVEAU and M. E. C. DE BoBer, Clin. chim. Acta 29 (1970), 219.

8 M. PAGet and P. Coustenoble, Annis Biol. clin. 24, 181 (1966).

9 B. Colfs and J. Verheyden, Clin. chim. Acta 18, 325 (1967).

10 E. E. HeER and R. A. MARGNI, Electro e Inmunoelectroforesis (G. Fernandez Editiones, Buenos Aires 1971).

11 R. T. Dunn, 21st. Nat. Meet. Am. Assac. clin. Chem. (1959).

12 These investigations were developed with the cooperation of the Instituto Antártico Argentino. 